UDC $519.21(045)$

DOI: $10.18372 / 1990-5548.56 .12946$

\author{
${ }^{1}$ Y. A. Opanasiuk, \\ ${ }^{2}$ B. I. Dmytrenko, \\ ${ }^{3}$ O. Y. Krasnousova
}

\title{
ERRORS ESTIMATION OF EXTERNAL DISTURBANCE INFLUENCES
}

\author{
${ }^{1,2,3}$ Educational\&Scientific Institute of Information-Diagnostics Systems, National Aviation University, \\ Kyiv, Ukraine \\ E-mail: ${ }^{1}$ yuriy.opanasiuk@gmail.com, ${ }^{2}$ dmytrenko@nau.edu.ua, ${ }^{3}$ o.krasnousova@gmail.com
}

\begin{abstract}
The main specific points of existing air navigation schemes with relation to external disturbing influences are discussed. Some new approach to analyze in the view of admissible temporal and spatial frames basic principle on which the simplest accelerometer may be constructed is proposed. It is shown that a strict successive analysis of accelerometer measurement procedure makes it possible to understand probable new source of errors in the value estimation of the disturbing force magnitude. If don't take into account these new possible errors any self-adjusting system of an airplane may be functionally damaged or at least functionally unreliable. These errors arise only when temporal duration of disturbing force is less than some critical time $\tau$, which depends on the given characteristics of an aircraft Inertial Navigation System and aircraft itself. The method of finding $\tau$ is discussed.
\end{abstract}

Index Terms-Inertial navigation system; aircraft; accelerometer; wave equation; disturbing influences; Lagrange function.

\section{I.INTRODUCTION}

The problems of navigation accuracy whose roots lay back in the mid-twentieth century should be extended now to meet the new challenges. Amongst these well-known challenges we would mention enormously high frequency of flights, continuously disproving environmental conditions, problems with airport landing and we should place in the first position the terrorist incidents in civil aviation which include aircraft hijacking, airlines bombing, terrorist attacks on airports. Common future of all above mentioned items is the extremely short segment of time available for checking out the health of the avionic system on the flight line or on the ground. Namely, this common point makes it possible to gather consideration of all these distinct situations within one theoretical framework and elaborate mathematical tools to construct admissible diagnostic procedures. Amongst all novel up-to-date challenges we should also mention the perspective of integrated commercial satellite system development of aircraft of civil aviation [1] and the creation of the low-cost gyro-free inertial navigation system (INS) [2]. Some new approach to elaborate theoretical framework to construct optimal flight safety diagnostic procedures was initiated in [3]. If the navigation schemes don't change they can become extinct, clearly, modern aircraft navigation system are being put at risk by the electronic devices that passengers carry on board, such as laptop computers and similar devices. Because of plethora of as mentioned and omitted anxiously important problems we should restrict ourselves to the analysis the most widespread inescapable external disturbing influences which of them differs of each other in the temporal duration.

\section{INERTIAL NAVIGATION SYSTEM}

Inertial Navigation System play anxiously important role in the modern aviation. The problem of INS construction dates from the early 20th century. The methods of INS continue to be an area of active research and from time to time had to be extended to meet the new challenge [1] - [11].

This chapter provides a brief introduction to navigation using inertial sensors, explaining only the underlining principles. Inertial sensors comprise accelerometers, which measure specific force and gyroscopes commonly abbreviated to gyros, which measure angular rate. An inertial measurement unit (IMU) combines multiple accelerometers and gyros, usually three of each, to produce three-dimensional measurements of specific forces and angular rate. By integrating these measurements and applying a gravity model, a position, velocity, and attitude solution may be maintained, a concept known as inertial navigation. Practical inertial navigation systems have been available from the $1950 \mathrm{~s}$, but were initially very large and expensive. In early INS, the sensors were physically aligned with the horizontal and vertical by mounting them on a 
platform connected to the host body by a series of gimbals driven by motors. This was known as a platform configuration and was due to the limitations of early gyro technology and the need to minimize the computational load. The strapdown configuration, whereby the sensors are aligned with the host body, was first proposed in 1962 with production of the first aircraft systems starting at the end of the 1970s. Today, it is almost universal [9].

In this chapter we restrict ourselves primarily to the analysis of accelerometers only because to the discussion of some peculiar features of their processing the next chapter will be devoted.

Accelerometers. Let us shortly consider a simple method to measure probable disturbing influences on a steady flying motion of an airplane [6].

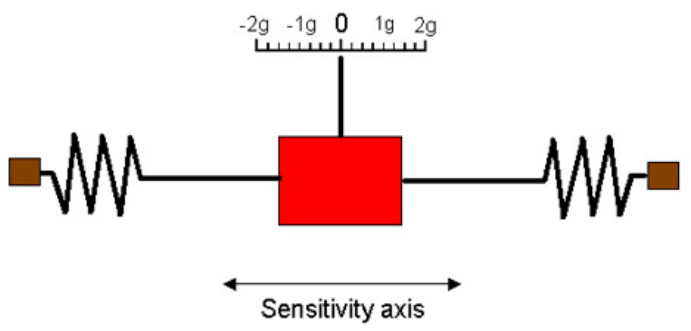

Fig. 1. Accelerometer principle

By attaching a mass to a spring, measuring its deflection, we get a simple accelerometer. An important exception is gravitational acceleration. This acts on the proof mass directly, not through the springs, and applies the same acceleration to all components of the accelerometer, so there is no relative motion of the mass with respect to the case. Therefore, the accelerometers sense only the nongravitational acceleration, known as specific force. Using three (or more) accelerometers we can form a $3 \mathrm{D}$ specific force measurement $f_{I B}^{B}$.

The model is composed of different function blocks based on Laplace transforms. In general, microelectronic accelerometer with a feedback control system is not a linear system. Standard assumptions and approximations are used to linearized the system.

The proof (test) mass is the sensing part of the accelerometer. It can be considered as a suspended mass-spring-damping system. Using Laplace transforms, the dynamic performance of the proof mass can be expressed as [12]:

$$
G_{1}(s)=\frac{\Delta l}{m a_{c}}=\frac{1}{m s^{2}+b s+k},
$$

where, $m, b$, and $k$ represent the mass, damping coefficient, and spring constant of the proof mass, respectively, $a_{c}$ is the external acceleration, and $\Delta l$ is the displacement of the proof mass. It is a typical two-order system.

So, we obtained the overall block diagram of the system:

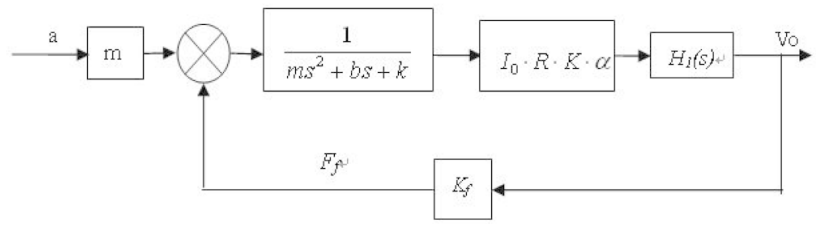

Fig. 2. Block diagram of microelectronic accelerometer system

Gyros. A device that senses angular rate with respect to inertial space is known as a gyroscope. Early gyroscopes used spinning mass technology. However, the vast majority of gyros used for navigation today are either optical or vibratory. An IMU containing a triad of gyros with mutuallyorthogonal sensitive axes measures the angular rate vector, $\omega_{I B}^{B}$ where the subscript IB denotes measurement of the axes of the IMU body frame with respect to an inertial frame and the superscript $b$ denotes that the components of the vector are resolved about the axes of the IMU body frame, which normally coincide with the gyro sensitive axes. Manned vehicles typically rotate at up to $3 \mathrm{rad} / \mathrm{s}(170 \mathrm{deg} / \mathrm{s})$. However, a gun-launched guided shell can rotate at up to $120 \mathrm{rad} / \mathrm{s}(6.800 \mathrm{deg} / \mathrm{s})$.

An IMU (giving $f_{I B}^{B}$ and $\omega_{I B}^{B}$ is sufficient to navigate relative to inertial space (no gravitation present), given initial values of velocity, position and attitude:

- integrating the sensed acceleration will give velocity;

- a second integration gives position;

- to integrate in the correct direction, attitude is needed.

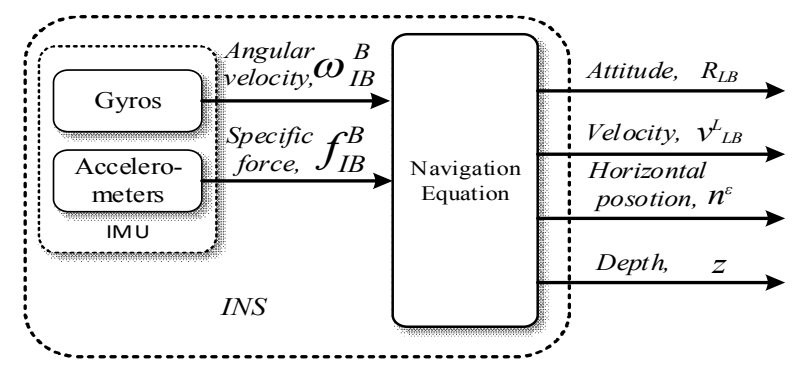

Fig. 3. Inertial Navigation System

This is obtained by integrating the sensed angular velocity. In terrestrial navigation (close to the Earth) we compensate for gravitation, and rotation of the Earth Equations integrating the gyro and accelerometer measurements into velocity, position and orientation are called navigation equations. The combination of an IMU and a computer running 
navigation equations is called an Inertial Navigation System.

\section{INERTIAL MEASUREMENT UNIT \\ ACCELEROMETERS AND INFLUENCE DURATION}

The previous consideration shows the extremely important role of damping forces in the realization of any practically significant scheme to construct an accelerometer. Strange as it seems but a presence of a damping force in the proof mass motion equation hides possibilities to discover some new sources of possible errors in disturbing force magnitude3 evaluation. So, this chapter purposely ignoring damping provides a strict successive analysis of accelerometer measurement procedure. Such a consideration makes it possible to understand probable source of errors in the value estimation of the disturbing force magnitude. The consequences of such errors may be anxiously substantial, so that can at some circumstances absolutely destroy the reliability any self-adjusting system of an airplane. Let consider a standard calculation schemes which is a starting point to elaborate their proper selfadjusting system. In the any local inertial frame (LIF) the total disturbing external force $F^{\text {ext }}$ according to the center-of-mass theorem gives birth to the acceleration $a_{c}$ of airplane

$$
a_{c}=\frac{F^{\mathrm{ext}}}{M},
$$

where, $M$ is airplane instant total mass which includes masses of all internal devices and instant amount of fuel. Of course, it is trivial approximate result ignoring after all the continuous descent of fuel. In the noninertial frame rigidly connected with accelerated vehicle (airplane or spacecraft) resulting instant net force $F(t)$ acting on accelerometer proof mass $m$ according to selected direction (Fig. 1) maybe write down as:

$$
F(t)=-k_{1} \Delta l_{1}(t)+k_{2} \Delta l_{2}(t)-m a_{c},
$$

where $k_{1}, \Delta l_{1}(t)$, stand accordingly for elasticity factor and a change in length of right spring, index "2" means the left spring. For simplicity we set $k_{1}=k_{2}=k$. Under condition $l_{1}+l_{2}=l=$ const we have $d l_{1}=-d l_{2}$, so $\Delta l_{1}=-\Delta l_{2} ;\left|\Delta l_{1}\right|=\left|\Delta l_{2}\right|=\Delta l$ substitution of these relation and (1) into (2), in the case when $F(t)=0$ gives

$$
m \frac{F^{\mathrm{ext}}}{M}=2 \kappa \Delta l
$$

So,

$$
F^{\mathrm{ext}}=\kappa \Delta l
$$

where, $\kappa=\frac{2 k M}{m}$ so called accelerometer factor.

But (4) is improperly derived formula - absence of forces means absence of accelerations but not of velocities. Moreover, (4) ignores time-dependence of $\Delta l$ and it is crucial in the case when the duration of influence is less that the time segment between zeroth and maximum value of $\Delta l$. Proper calculations can be realized using the work-energy theorem, also known as kinetic energy increase theorem, which states that the work done by all forces (including fictitious one) acting on a particle equals the change in the particles kinetic energy. It is customary in theoretical physics to denote kinetic energy as $T$, so change in the kinetic energy should be denoted as $\Delta T$. How accelerometers proof mass approaches to its halt? How its position depends on time? The answers on these questions may describe correlation between duration of influence and data for self-adjusting system and somehow avoid extremely high errors in the estimation of the disturbing force. To answer on these questions we should use the above mentioned theorem and introduce oriented along motion (Fig. 1) coordinate axis $x$, which origin coincides with initial rest-point of accelerometer mass $m$. So, we can wright down

$$
\Delta T=\int_{0}^{\Delta l(t)}\left(2 k \Delta l(t)-m a_{c}\right) d x,
$$

Suppose that accelerometer mass approaches to its halt at time $\Delta t=\tau$, which means $\Delta T=0$, so (5) may be rewritten as

$$
2 \int_{0}^{\Delta l(t)} k \Delta l(t) d x-m \int_{0}^{\Delta l(t)} m a_{c} d x=0,
$$

After integration using all above mentioned relations we get simple equation

$$
2 k(\Delta l(t))^{2}-m a_{c} \Delta l(\tau)=0,
$$

which has two solutions: first $\Delta l(\tau)=0$ that means the initial position, when disturbing forces begin to act and second

$$
\Delta l(\tau)=\frac{m a_{c}}{2 k}=\frac{m F^{\mathrm{ext}}}{2 M k},
$$

from which we exactly derive relation (4), noting that $\Delta l(\tau)=2 \Delta l$.

Suppose now that time segment $\Delta t$ of disturbing force $F^{\text {ext }}$ action is less than $\tau$, i.e. $\Delta t<\tau$. In this case using in all existing IMU schemes relation (4) is incorrect and we deal with enormously large errors in evaluating of $F^{\text {ext }}$. So, we should return to the equation (5) in which at this time $\Delta T \neq 0$ and we 
have opportune y to find answer the questions what should be after the moment of a disappearance of a disturbing force $F^{\text {ext }}$ and how we can properly evaluate the $F^{\mathrm{ext}}$ in this case. After the moment when external influence become extinct accelerometer proof mass $m$ continues to move. In accelerated frame Lagrange function $L$ has the form [13]

$$
L=\frac{m \dot{x}^{2}}{2}=m a_{c} x-U,
$$

where, $U=\frac{m x^{2}}{2}$ and proper equations of motion, which correspond to Lagrange function (9) are integrating in general form. At that we should not even write down original motion equation and can start right away from its first integral $E$. So, for Lagrange function (9) we have

$$
E=\frac{m \dot{x}^{2}}{2}=m a_{c} x+U,
$$

This is the first order differential equation. Integration yields

$$
\frac{d x}{d t}=\sqrt{\frac{2}{m}\left[E-U(x)-m a_{c} x\right.},
$$

after integration we obtain for $t$

$$
t=\sqrt{\frac{m}{2}} \int \frac{d x}{\sqrt{E-U(x)-m a_{c}}}+\tau_{0} .
$$

Integration constants $E$ and $\tau_{0}$ play role of fitting parameters, which allow apply this quite general framework to every given real data. A simple consideration shows that at such circumstances the maximum value of $\Delta l$ should be observed in the case of continuous presence of disturbing force, which can be evaluated by means of formula (4). Consequences of this consideration provide unexpected result: shorter then $\tau$ temporal duration of disturbing force may be estimated as less in magnitude than real acting force.

\section{CONCLUSIONS}

A strict successive analysis of accelerometer measurement procedure makes it possible to understand probable new source of errors in the value estimation of the disturbing force magnitude. The consequences of such errors may be at some circumstances anxiously substantial. If don't take into account these new possible errors any selfadjusting system of an airplane may be functionally damaged or become almost unreliable This errors arise only when temporal duration of disturbing force is less than some critical time $\tau$, which depends on some characteristics of an aircraft INS, and aircraft itself. The method of finding $\tau$ is given. This conclusion is valid only for influences shorter or equal to some critical duration which can be evaluated by means of formula (4). Further descend of disturbing duration makes all above discussed INS methods to be extinct, and influences on aircrafts should be described by means of 3D wave equation and its solutions, known as plane waves. For the investigation of these problems and also for the consideration of the extended (to involve damping) previous analysis will be devoted future publications.

\section{REFERENCES}

[1] V. M. Sineglasov and F. M. Zaharin, "Perspectives of integrated inertial-satellite systems development of aircraft of civil aviation," 2-nd International Conference "Methods and Systems of Navigation and Motion Control". Proceedings. Oct. 9-12, 2012, Kyiv, Ukraine.

[2] V. Laria and A. Tunik, "Gyro-free accelerometer based SINS: Algorithms and Structures," 2-nd International Conference "Methods and Systems of Navigation and Motion Control". Proceedings. Oct. 9-12, 2012, Kyiv, Ukraine.

[3] Y. Opanasiuk, "Theoretical framework to construct optimal flights safety diagnostic procedures," 2-nd International Conference "Methods and Systems of Navigation and Motion Control". Proceedings. Oct. 9-12, 2012, Kyiv, Ukraine.

[4] Kenneth R. Britting. Inertial Navigation System Analysis, John Wiley\&Sons, 1971

[5] Jack B. Kuipers, Quaternions and Rotation Sequences: a primer with Applications to Orbit Aerospace and virtual reality. Princeton University Press, 1999.

[6] Introduction to Inertial Navigation

http://www.navlab.net/Publications/Introduction_to_Inerti al_Navigation.pdf

[7] D. N. Pitterman and C. E. Roberts, "Determining Inertial Errors from Navigation-in-place Date" Proc. Of the IEEE Position Location and Navigation Symposium, 2001, pp. 60-67.

[8] A. E. Bryson, Control Spacecraft and Aircraft, Prinston University Press, Prinston, NY, 1993

[9]. Paul D. Grove Navigation using Inertial sensors. IEEE Aerospace and Electronic Systems Magazine 30(2): 42-69, 2015

[10]T. F. Weiner, "Theoretical analysis of gimballess inertial reference equipment using delta-modulated instruments," 1962.

[11]P. G. Savage, "Blazing gyros: The evolution of strapdown inertial navigation technology for 
aircraft," Journal of Guidance Control and Dynamics, pp. 637-655, June 2013.

[12] W. Xue, J. Wang, and T. H. Cui, "Modeling and Design of Polymer-Based Tunneling Accelerometers by ANSYS/MATLAB," J. Trans. Mechatron. vol. 10, pp. 468-471, 2005.

[13]L. D. Landau and E. M. Lifshits, Mechanics, Third Edition. Moscow, "Nauka”, 1973, (in Russian).

Received April 12, 2018

OpanasiukYuriy. Senior Lecturer.

Education\&Scientific Institute of Information-Diagnostics Systems, National Aviation University, Kyiv, Ukraine.

Education: Taras Shevchenko National University, Kyiv, Ukraine, (1973).

Research area: optimal control, information theory, general relativity and cosmology.

Publications: 58.

E-mail: yuriy.opanasiuk@gmail.com

Dmytrenko Bohdan. Assistant.

Education\&Scientific Institute of Information-Diagnostics Systems, National Aviation University, Kyiv, Ukraine.

Education: National Technical University of Ukraine "Kyiv Politechnic Institute", (1999).

Research area: automated systems, CAD, CAM, windenergy.

Publications: 22.

E-mail: dmytrenko@nau.edu.ua

Krasnousova Olga. Candidate of Science (Engineering).

Education\&Scientific Institute of Information-Diagnostics Systems, National Aviation University, Kyiv, Ukraine.

Education: Kyiv Institute of Civil Aviation Engineers, Kyiv, Ukraine, (1995).

Research area: statistical methods of radioelectronic systems quality control.

Publications: 26.

E-mail: o.krasnousova@gmail.com

\section{Ю. А. Опанасюк, Б. І. Дмитренко, О. Ю. Красноусова. Помилки оцінювання зовнішніх збурюючих} впливів

Проаналізовано поведінку інерціальної навігаційної системи літального апарату при наявності різних за тривалістю у часі зовнішніх збурюючих впливів. Запропоновано новий підхід до аналізу основного принципу, що визначає роботу найпростішого акселерометра. Показано, що послідовний строгий аналіз процесу вимірювання дає можливість виявити певне нове джерело помилок в оцінюванні величини збурюючого впливу. Показано, що якщо не брати до уваги ці можливі похибки, то будь-яка самоналаштовувальна система літака може бути функціонально пошкодженою чи, принаймні, функціонально ненадійною. Ці похибки виникають тільки за умови, що тривалість у часі збурюючого впливу є меншою певного критичного значення $\tau$, котре залежить від конкретних характеристик інерціальної навігаційної системи та власне самого літака. Запропоновано метод визначення $\tau$.

Ключові слова: інерціальна навігаційна система; літальний апарат; акселерометр; збурюючі впливи; хвильове рівняння; функція Лагранжа.

Опанасюк Юрій Арценович. Старший викладач.

Навчально-науковий інститут інформаційно-діагностичних систем, Національний авіаційний університет, Київ, Україна.

Освіта: Національний університет ім. Тараса Шевченка, Київ, Україна, (1973).

Напрям наукової діяльності: теорія тяжіння та загальна теорія відносності, астрофізика та космологія, релятивістська динаміка, аеронавігація.

Кількість публікацій: 58.

E-mail: yuriy.opanasiuk@gmail.com

Дмитренко Богдан Іванович. Асистент.

Навчально-науковий інститут інформаційно-діагностичних систем, Національний авіаційний університет, Київ, Україна.

Освіта: Національний технічний Університет України «Київський політехнічний інститут» ім.Ігоря Сикорського, (1999).

Напрям наукової діяльності: автоматизовані системи, вітроенергетика.

Кількість публікацій: 22.

E-mail: dmytrenko@nau.edu.ua 
Красноусова Ольга Юрьївна. Кандидат технічних наук.

Навчально-науковий інститут інформаційно-діагностичних систем, Національний авіаційний університет, Київ, Україна.

Освіта: Київський інститут інженерів цивільної авіації, (1995).

Напрям наукової діяльності: статистичні методи контролю якості радіоелектронних систем.

Кількість публікацій: 26.

E-mail: o.krasnousova@gmail.com

Ю. А. Опанасюк, Б. И. Дмитренко, О. Ю. Красноусова. Ошибки оценивания внешних возмущающих воздействий

Проведен анализ поведения инерциальной навигационной системы летательного аппарата при различных по времени внешних возмущениях. Предложен новый подход к анализу основного принципа, на котором основана работа простейшего акселерометра. Показано, что строгий последовательный анализ процесса измерения акселерометром позволяет обнаружить некий новый источник ошибок оценивания величины возмущающего воздействия. Показано, что, если не принимать во внимание эти возможные ошибки, то любая самонастраивающаяся система самолета может быть функционально повреждена или, по крайней мере, функционально не надежной. Эти ошибки возникают только при условии, когда временная продолжительность возмущающего воздействия меньше некоторого критического значения $\tau$, что зависит от конкретных характеристик инерциальной навигационной системы и самого самолета. Предложен метод определения $\tau$.

Ключевые слова: инерциальная навигационная система; летательный аппарат; акселерометр; возмущающие воздействия; волновое уравнение; функция Лагранжа.

Опанасюк Юрий Арценович. Старший преподаватель.

Учебно-научный институт информационно-диагностических систем, Национальный авиационный университет, Киев, Украина.

Образование: Национальный университет им. Тараса Шевченко, Киев, Украина, (1973).

Направление научной деятельности: теория тяготения и общая теория относительности, астрофизика и космология, релятивистская динамика, аэронавигация.

Количество публикаций: 58.

E-mail: yuriy.opanasiuk@gmail.com

Дмитренко Богдан Иванович. Ассистент.

Учебно-научный институт информационно-диагностических систем, Национальный авиационный университет, Киев, Украина.

Образование: Национальный технический Университет Украины «Киевский политехнический институт»им. Игоря Сикорского, (1999).

Направление научной деятельности: автоматизированные системы, ветроенергетика

Количество публикаций: 22.

E-mail: dmytrenko@nau.edu.ua

Красноусова Ольга Юрьевна. Кандидат технических наук.

Учебно-научный институт информационно-диагностических систем, Национальный авиационный университет, Киев, Украина.

Образование: Киевский институт инженеров гражданской авиации, (1995).

Направление научной деятельности: статистические методы контроля качества радиоэлектронных систем.

Количество публикаций: 26.

E-mail: o.krasnousova@gmail.com 